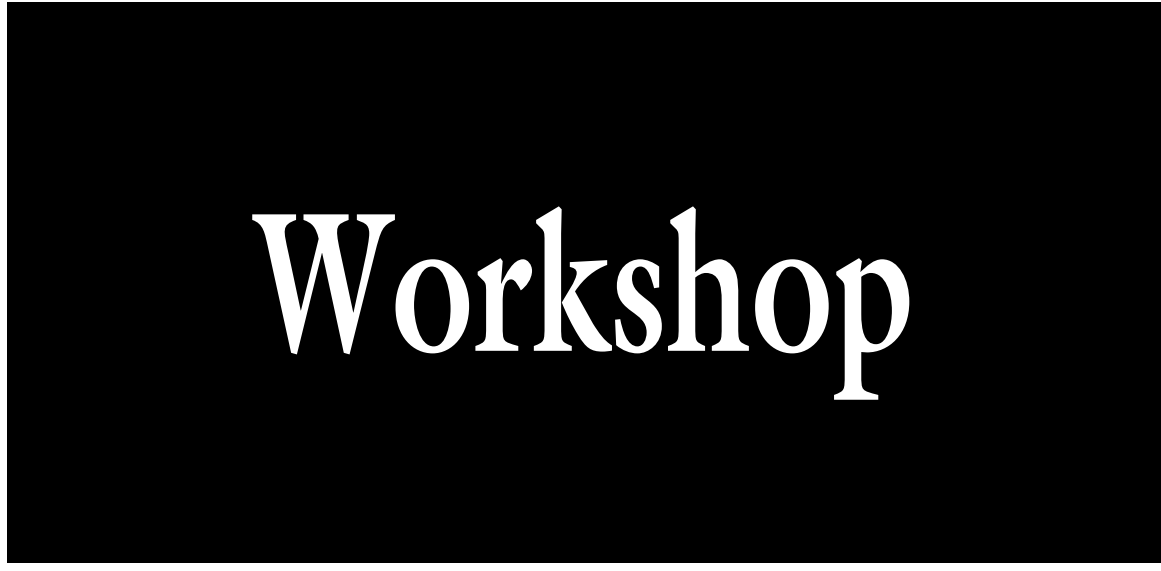

\title{
Developing a National Strategic Plan for Consumer Horticulture
}

\author{
Lucy K. Bradley ${ }^{1,10}$, Ellen M. Bauske ${ }^{2}$, Thomas A. Bewick ${ }^{3}$, \\ John R. Clark ${ }^{4}$, Richard. E. Durham ${ }^{5}$, Gail Langellotto ${ }^{6}$, \\ Mary H. Meyer ${ }^{7}$, Margaret Pooler ${ }^{8}$, and Sheri Dorn ${ }^{9}$
}

ADDITIONAL INDEX WORDs. gardening, funding, stakeholder

SUMMARY. Consumer horticulture encompasses a wide array of activities that are practiced by and of interest to the gardening public, garden-focused nongovernmental organizations, and gardening-related industries. In a previous publication, we described the current lack of funding for research, extension, and education in consumer horticulture and outlined the need for a strategic plan. Here, we describe our process and progress in crafting a plan to guide university efforts in consumer horticulture, and to unite these efforts with stakeholders' goals. In 2015, a steering committee developed a first draft of a plan, including a mission statement, aspirational vision, core values, goals, and objectives. This draft was subsequently presented to and vetted by stakeholders at the 2015 American Society for Horticultural Science Consumer Horticulture and Master Gardeners (CHMG) working group workshop, a 2015 Extension Master Gardener Coordinators' webinar, and a 2015 meeting in Washington, DC. Feedback received from these events is being used to refine and focus plan goals and objectives. The most recent working draft of the plan can be found on the website, where stakeholders and other interested parties can register to receive updates and to provide input into the process.

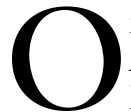

n 31 July 2014 at the ASHS Annual Conference in Orlando, FL, the CHMG working group outlined the need for a national strategic plan for consumer horticulture (Bauske et al., 2015). The scope of consumer horticulture is broad; it encompasses both interior and exterior cultivation of ornamental and food plants in residential, commercial, and public spaces, as well as in community and school gardens. Consumer horticulture embraces a broad range of activities of interest to the gardening public (Bauske et al., 2014). Consumer horticulture influences the environment in many ways, affecting water quality and quantity, waste management, wildlife, and other aspects of environmental sustainability (Carey et al., 2013; Zhou, 2014). Consumer horticulture can foster ecosystem services, such as storm water management, temperature regulation, pest control, conservation of biodiversity, sequestration of carbon, and pollination (Lin et al., 2015; Lovell and Taylor, 2013; Wilde et al., 2015). Consumer horticulture also benefits human health and well-being (Hall and Dickson, 2011) via cultural, therapeutic, recreational, and educational services.

In $2008,31 \%$ of all U.S. households (an estimated 36 million households) participated in food gardening (National Gardening Association, 2009), and the number increases annually (Butterfield, 2013). These gardeners represent a broad cross-section of the
U.S. population and include all ages, ethnicities, education levels, income levels, marital statuses, household sizes, genders, and regional locations. Consumer horticulture stakeholders also include the 83,389 Extension Master Gardener (EMG) volunteers in the United States and Canada (Extension Master Gardener National Committee, 2015).

Consumer horticulture has driven a robust wholesale and retail industry (Vilsack and Reilly, 2015). National chain stores, independent local retailers, farmers markets, nurseries, and other businesses create and sell seeds, plants, tools, clothes, artwork, and other goods and services to the gardening public. Commercial businesses offer new and experienced gardeners specialized classes, workshops, retreats, and tours. Authors of traditional and social media write books, blogs, and magazine articles for gardeners and homesteaders. Television shows, radio shows, and podcasts further cater to the gardening public.

Given the environmental, health, social, and economic impact of consumer horticulture, it is surprising that a national vision for consumer horticulture does not already exist to guide research, education, and extension programs in land-grant universities and other public and private research efforts. In response to this void, a small group of stakeholders has created the National Initiative for Consumer Horticulture (NICH). This group has undertaken the development of a preliminary national strategic plan for consumer horticulture. The history of the planning process, the benefits of a strategic plan, as well as an overview of the preliminary plan were presented to 46 participants at the $\mathrm{CHMG}$ working group workshop held 6 Aug. 2015 at the ASHS Annual Conference (Bauske, 2015). Input from workshop participants has been incorporated into the preliminary plan. An overarching goal of this plan is to unite national research efforts with the goals of the diverse stakeholders in the industry, the public sector, and the gardening public to advance knowledge and increase the benefits and application of horticulture for an improved quality of life.

\section{Materials and methods}

The preliminary strategic plan was developed using the process previously outlined by Dr. Thomas Bewick (Bauske et al., 2015). A core 
leadership group invited representatives from universities, nonprofit commercial industry, EMG volunteers, and administration. The steering committee consisted of 13 members; it was small enough to reach consensus and yet as diverse as practical. The members included Dr. Ellen Bauske (The Georgia Center for Urban Agriculture, University of Georgia, Griffin, GA), Dr. Thomas Bewick [U.S. Department of Agriculture (USDA), National Program Leader, Horticulture, Washington, DC], Dr. Lucy Bradley (Department of Horticultural Science, North Carolina State University, Raleigh, NC), Mark Broxon (Proven Winners LLC, Sycamore, IL), Dr. Rick Durham (Department of Horticulture, University of Kentucky, Lexington, KY), Maree Gaetani (Gardeners Supply Co., Burlington, VT), Bob Kellam (Extension Master Gardener Volunteer, Raleigh, NC), Dr. Gail Langellotto (Department of Horticulture, Oregon State University, Corvallis, OR), Penny McBride (Vertical Harvest, Jackson, WY), Dr. Mary Meyer (Department of Horticultural Science, University of Minnesota, Chaska,

This paper was part of the workshop "Moving the National Strategic Plan for Consumer Horticulture, Research, Education, and Extension Forward: Creative Destruction and Rebuilding" held 6 Aug. 2015 at the ASHS Conference, New Orleans, LA, and sponsored by the Consumer Horticulture and Master Gardeners Working Group.

Funding for this research was provided by the Facilitating the Development of a National Strategic Plan for Consumer Horticulture (USDA-NIFA-2015-38831-24022).

${ }^{1}$ Department of Horticultural Science, North Carolina State University, Campus Box 7609, Kilgore Hall 128, 2721 Founders Drive, Raleigh, NC 27695

${ }^{2}$ Center for Urban Agriculture, University of Georgia, 1109 Experiment Station, Griffin, GA 30223

${ }^{3}$ Institute of Food, Production and Sustainability, National Institute of Food and Agriculture, U.S Department of Agriculture, 1400 Independence Avenue SW, Mailstop 2240, Washington, DC 20250

${ }^{4}$ Department of Horticulture, University of Arkansas, 316 Plant Sciences Building, Fayetteville, AR 72701

${ }^{5}$ Department of Horticulture, University of Kentucky, N-308G Agricultural Science North, Lexington KY 40546

${ }^{6}$ Department of Horticulture, Oregon State University, 4017 Agricultural and Life Sciences Building, Corvallis, OR 97331

${ }^{7}$ University of Minnesota, 424 Alderman Hall, 1970 Folwell Avenue, Saint Paul, MN 55108

${ }^{8}$ U.S. National Arboretum, Agricultural Research Service, U.S. Department of Agriculture, 10300 Baltimore Avenue, Beltsville, MD 20705

${ }^{9}$ Department of Horticulture, University of Georgia, 1109 Experiment Station, Griffin, GA 30223

${ }^{10}$ Corresponding author. E-mail: lucy_bradley@ncsu.edu.

This is an open access article distributed under the CC BY-NC-ND license (http://creativecommons.org/ licenses/by-nc-nd/4.0/).
MN), Dr. Margaret Pooler (USDA, Agricultural Research Service, U.S. National Arboretum, Beltsville, MD), Casey Sclar (American Public Gardens Association, Kennett Square, PA), and Jenn Tedeschi (National Gardening Association, Williston, VT).

The steering committee met weekly via telephone and online conferencing technology to draft a strategic plan. They developed a working definition of consumer horticulture and created a preliminary strategic plan. The plan included a mission statement, a group vision, core values, and seven goals, each with specific objectives (Table 1).

This plan was presented for discussion and modification on 6 Aug. 2015 at the ASHS Annual Conference in New Orleans, LA, in the CHMG working group workshop. Participants included consumer horticulture Extension agents and specialists, as well as other ASHS members connected to consumer horticulture, including economists and department heads. Dr. Ellen Bauske, introduced the steering committee members and reviewed the history of the plan development (Bauske et al., 2015); former ASHS president Dr. John Clark, one of the many participants in the planning of the Specialty Crop Research Initiative [SCRI (National Institute of Food and Agriculture, n.d.)], highlighted the benefits of strategic planning; and Dr. Thomas Bewick, introduced the plan and lead the discussion of modifications and changes.

The plan was then vetted during the 19 Aug. 2015 National EMG Coordinators' monthly webinar. Dr. Lucy Bradley presented the preliminary plan and facilitated an online discussion to solicit input from the 35 participants. Comments from participants at both events have been integrated into Table 1 .

Next, NICH convened 29 representatives from a wide array of consumer horticulture associations, industry, public gardens, universities, volunteers, and agencies at the U.S. National Arboretum in Washington, DC, on 4 and 5 Nov. 2015. The participants reviewed the progress of the steering committee, developed strategies for each objective, created working groups for each goal, and reviewed potential organizational structures.

\section{Results and discussion}

$S$ TRATEGIC PLANNING IS IMPACTFUL. At the workshop, Dr. John Clark explained how the SCRI national strategic plan created shared goals and collective energy. The planning process and plan increased visibility and recognizable significance of specialty crops and carried this message to appropriate audiences, ultimately resulting in the SCRI. As he noted, the plan "yielded progress beyond our dreams." He further shared that, as with the consumer horticulture initiative, Dr. Thomas Bewick provided leadership to first define specialty crops, then focused on a shared agenda that benefited many. Before creating the strategic plan and developing the name "specialty crops" in 2007, these horticulture crops (previously called "minor") were virtually unknown, although they provide a significant portion of America's farm gate value. The SCRI, Specialty Crop Block Grant Program (USDA, 2014), and the National Clean Plant Network (University of California, 2016) are results of that strategic planning process and were integrated into the national agricultural funding system. The term "specialty crops" has gone from being virtually unknown to being a household word in less than 10 years. As Dr. John Clark pointed out, "People routinely state 'specialty crops' in public. Not minor, not horticultural, Not Insignificant." He pointed out that money and supportive votes go together in Congress and that the strategic plan helped them document economic impact.

Dr. John Clark also noted the vast number of consumer horticulture practitioners and the wide variety of impacts including food, societal value, health, and ecosystem services. He encouraged the working group to define the message and identify the best way to deliver it, including who would be the best messengers. He challenged the working group to identify supporters who make policy and budget decisions, and to focus on how the strategic plan will benefit them. Dr. John Clark suggested that the working group must identify specific goals, such as increased funding or more visibility.

Dr. John Clark also shared the potential direct benefits to ASHS members who participate in the strategic planning process. Their involvement and contributions would lead to scholarly publications, presentations, opportunities for national leadership, and professional "credit," while also leading to the generation of funding for 


\section{WORKSHOP}

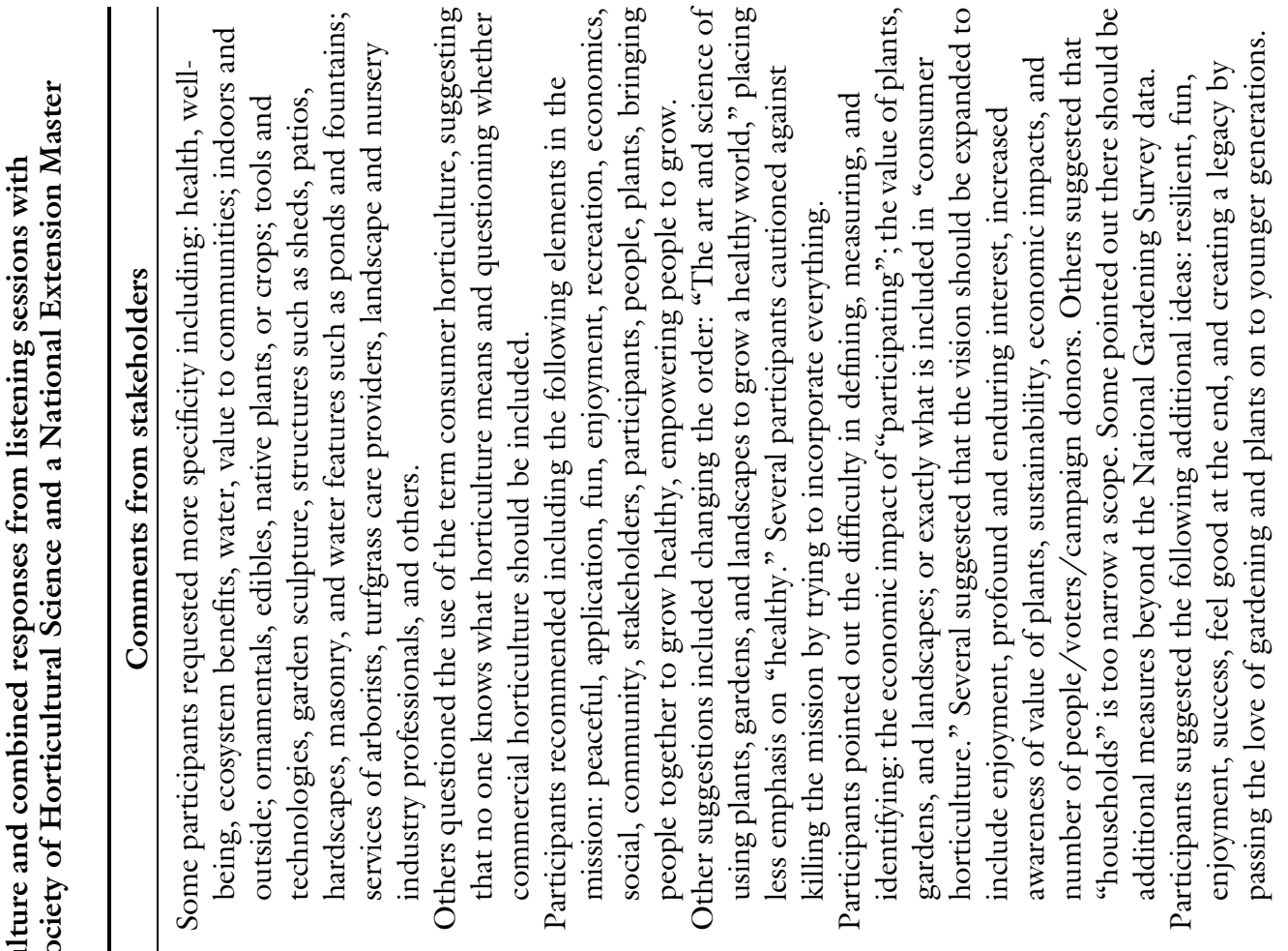

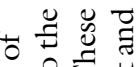

\section{过}

$\forall$ ㄹ

泀苛苞

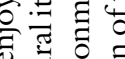

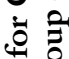

0

. 


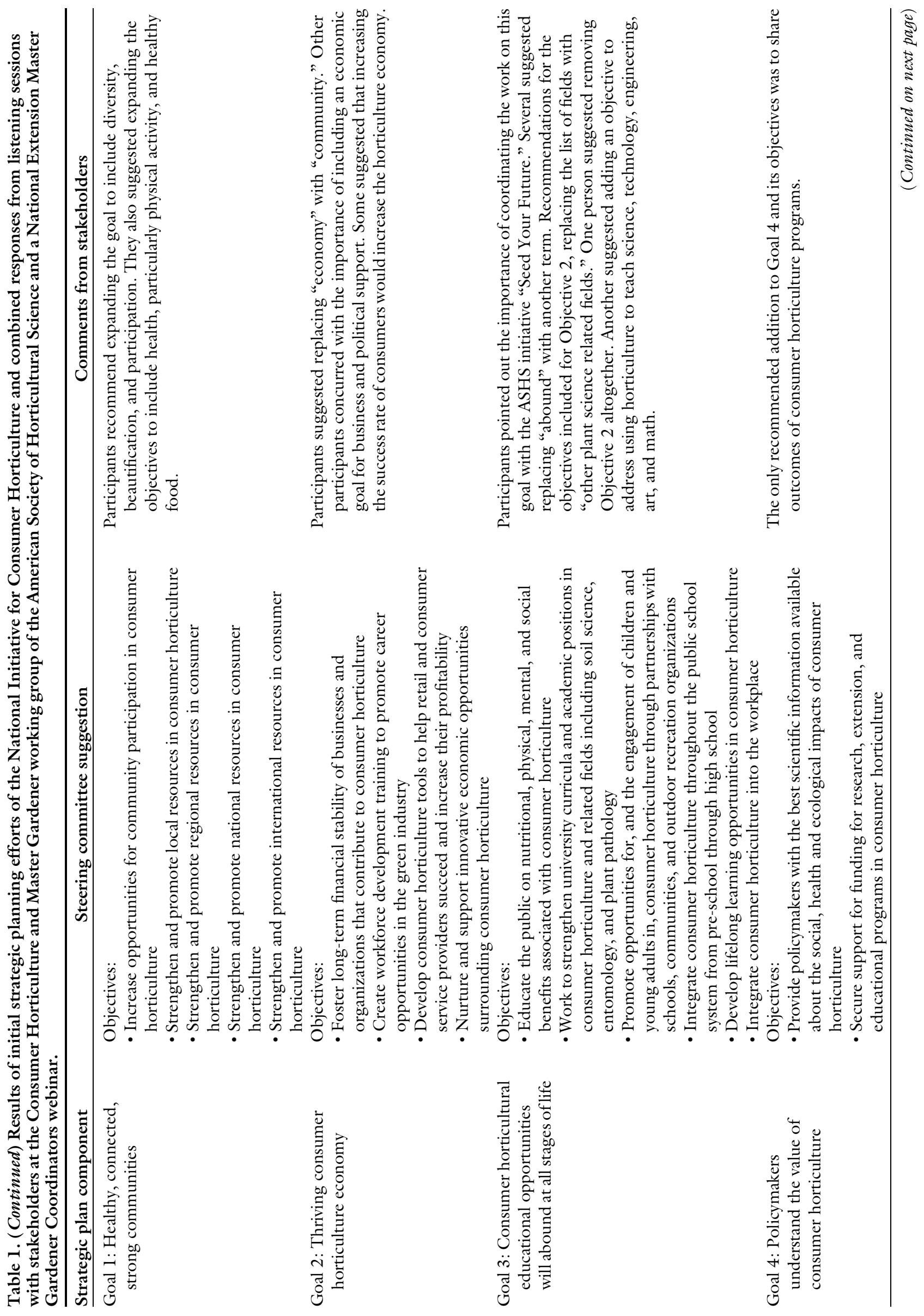

Hortlechnology • August 2016 26(4) 


\section{WORKSHOP}

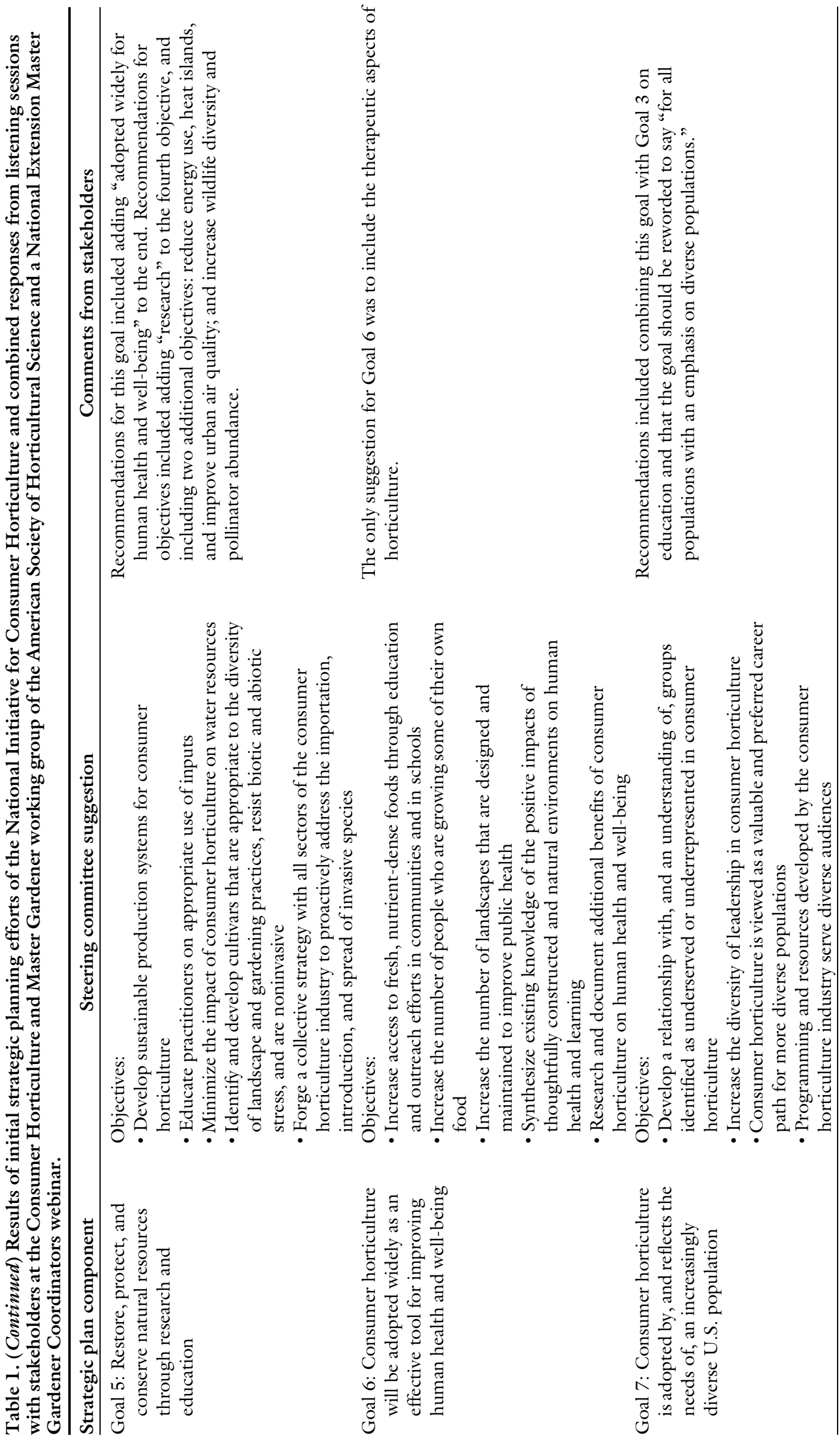


consumer horticulture research. He encouraged the CHMG working group to also consider the benefits to industry, including new products, increased profits, and increased visibility. Finally, Dr. John Clark encouraged the working group to take advantage of all the support that ASHS can offer, including gathering at ASHS meetings and using ASHS tools and networks to publicize the plan and find additional agency and political support.

Presentation and Discussion OF THE PRELIMINARY STRATEGIC PLAN FOR THE NATIONAL INITIATIVE FOR CONSUMER HORTICUlTuRE. After Dr. Ellen Bauske's and Dr. John Clark's presentations, Dr. Thomas Bewick defined the ground rules for the planning process. While encouraging all to participate in crafting the plan, he advised participants not to focus on wordsmithing, which would be done later. He identified two goals for the meeting: 1) Obtaining "practical consensus" (which he defined as "when no one objects so strongly to an idea that they are unwilling to go along with that idea, at least this time, for now") and 2) recruiting new members for the NICH. Dr. Bewick then introduced the preliminary strategic plan, including the definition of consumer horticulture, and the project's mission, vision, core values, and goals. Both the initial draft and the feedback from participants are presented in Table 1.

Once the preliminary strategic plan had been presented, Dr. Bewick led a discussion of the overall plan. This group of stakeholders focused on the goals. Some participants suggested that fewer goals might be easier to manage; others noted that reducing the number of goals might make it harder for stakeholders to connect. Another participant suggested that reorganizing the goals into subject areas would make it easier to recruit team members into specific areas of interest, such as soils or water. Some participants requested that the concepts of enjoyment, success, and diversity be woven throughout all the goals.

Another participant stated that Goal 2, A thriving borticulture economy, drives everything. Producers and key retailers wield a great deal of the economic power but are focused on production and seem disconnected from consumers. The participant urged that the plan should include spending time listening, watching, and understanding consumers. There was strong agreement among workshop participants with this comment and strong support for the development of a marketing plan with strategic language.

Although there was much discussion about the specifics of the goals, there was strong general agreement about the concepts encompassed in the plan's seven strategic goals, and no missing focus areas were identified by the group.

The plan was also presented to the national EMG coordinators at an online meeting on 19 Aug. 2015. The 35 participants were very supportive of the plan, and their recommendations have been integrated with those of the ASHS participants in column 3 of Table 1.

Interestingly, the representatives at the NICH meeting in November made few comments on the number of goals, but focused on the vision and mission statements. Their suggestions are also included in Table 1 . The participants developed strategies for achieving the seven goals, but reached no consensus on leadership for NICH going forward. The strategies developed have been posted on the NICH website (NICH, 2016).

\section{Conclusions and next steps}

The NICH will develop a national, focused, collective vision and voice. Our goals are to capitalize on the collective knowledge, networks, and energy of the consumer horticulture field, to increase visibility and recognizable significance, and to carry the message to appropriate audiences. We will build consumer gardening confidence and success; maximize the economic, health, social, and environmental benefits of gardening; and increase value for plants, gardens, and landscapes.

The vetting process of the strategic plan will continue nationwide. The input received from the initial workshops will be synthesized and integrated into options that will be distributed via an online survey to solicit additional input and move us toward consensus. A second national workshop is planned for Summer 2016 where the focus will be on review of the revised mission, vision and goals, adoption and staffing of an organizational structure, and development of specific objectives for each goal. The results of this process will be posted on the NICH website. The website is a vehicle for collecting general input, hosting surveys to collect specific plan input, and announcing future meetings and meeting results. One can register for updates, review progress, suggest partners, and contact working group chairs on the site. There are many opportunities to engage in the process (NICH, 2016).

\section{Literature cited}

Bauske, E.M. 2015. Moving the national strategic plan for consumer horticulture research, education, and extension forward: Creative destruction and rebuilding. HortScience 49:S96 (abstr.).

Bauske, E.M., G.R. Bachman, T. Bewick, L.K. Bradley, D. Close, R. Durham, and M.H. Meyer. 2015. The case for a national strategic plan for consumer horticulture research, education, and extension. HortTechnology 25:477-479.

Bauske, E.M., G.R. Bachman, L.K. Bradley, K. Jeannette, A. Stoven O'Connor, and P.J. Bennett. 2014. Consumer horticulture outreach: Communication challenges and solutions. HortTechnology 24:266-269.

Butterfield, B. 2013. New 2013 national gardening survey. 27 June 2016. <http:// www.garden.org/articles/articles.php? $\mathrm{q}=$ show\&id $=3737>$.

Carey, R.O., G.J. Hochmuth, C.J. Martinez, T.H. Boyer, M.D. Dukes, G.S. Toor, and J.L. Cisar. 2013. Evaluating nutrient impacts in urban watersheds: Challenges and research opportunities. Environ. Pollut. 173:138-149.

Extension Master Gardener National Committee. 2015. 2015 Extension Master Gardener Survey. 27 June 2016. <http:// articles.extension.org/sites/default/files/ EMG\%20Infocard\%202016_0.pdf>.

Hall, C.R. and M.W. Dickson. 2011. Economic, environmental, and health/ well-being benefits associated with green industry products and services: A review. J. Environ. Hort. 29:96-103.

Lin, B.B., S.M. Philpott, and S. Jha. 2015. The future of urban agriculture and biodiversity-ecosystem services: Challenges and next steps. Basic Appl. Ecol. 16:189-201.

Lovell, S.T. and J.R. Taylor. 2013. Supplying urban ecosystem services through multifunctional green infrastructure in the United States. Landscape Ecol. 28: 1447-1463.

National Gardening Association. 2009. The impact of home and community gardening in America. Scotts Miracle-Gro Co., Marysville, $\mathrm{OH}$.

National Initiative for Consumer Horticulture (NICH). 2016. Growing a healthy world through the art and science of plants, gardens and landscapes. 27 June 2016. <http://www.consumerhort.org $>$. 


\section{WORKSHOP}

National Institute of Food and Agriculture. (n.d.). Specialty crop research initiative. 27 June 2016. <http://nifa.usda. gov/funding-opportunity/specialtycrop-research-initiative-scri>.

U.S. Department of Agriculture (USDA). 2014. USDA announces specialty crop block grant program-Historic farm bill support available through state departments of agriculture. 27 June 2016. <http://www.usda.gov/wps/portal/ usda/usdahome? contentidonly=true $\&$ contentid=2014/04/0064.xml>.

University of California. 2016. National clean plant network. 27 June 2016. $<$ http://nationalcleanplantnetwork.org/>.

Vilsack, T. and J. Reilly. 2015. Census of horticultural specialties (2014), Vol. 3, Special studies, Part 3. AC-12-SS-3. U.S. Dept. Agr. 27 June 2016. <http://www.agcensus.
usda.gov/Publications/2012/Online_ Resources/Census_of_Horticulture_ Specialties/HORTIC.pdf>.

Wilde, H.D., K.J.K. Gandhi, and G. Colson. 2015. State of the science and challenges of breeding landscape plants with ecological function. 27 June 2016. <http://www. nature.com/articles/hortres201469>.

Zhou, Q. 2014. A review of sustainable urban drainages systems considering the climate change and urbanization impacts. Water 6:976-992. 